\title{
Comparative analysis of Irish potato (Solanum tuberosum L.) production in the farming sectors that emerged from Zimbabwe's radical Land Reform of 2000
}

\author{
O. Svubure ${ }^{1,2, *}$, P.C. Struik ${ }^{2}$, A.J. Haverkort ${ }^{3,4}$, J.M. Steyn ${ }^{4}$ \\ ${ }^{I}$ Chinhoyi University of Technology, Department of Irrigation and Water Engineering, Chinhoyi, Zimbabwe \\ ${ }^{2}$ Centre for Crop Systems Analysis, Wageningen University and Research Centre, Wageningen, The Netherlands \\ ${ }^{3}$ Plant Research International, Wageningen University and Research Centre, Wageningen, The Netherlands \\ ${ }^{4}$ Department of Plant Production and Soil Science, University of Pretoria, Pretoria, South Africa \\ *Corresponding author: \\ Email address: svubure.oniward@wur.nl, osvub@yahoo.com \\ Postal address: Centre for Crop systems Analysis, Wageningen University and Research \\ Centre, PO Box 430, 6700AK, Wageningen, The Netherlands \\ Tel: $+31(0) 317485315$ \\ Fax: $+31(0) 317485572$
}

\begin{abstract}
Irish potato production in Zimbabwe can be traced back to the early 1900s. Large-scale commercial farmers dominated production till the early 2000s. Potato is the most important horticultural crop and has been declared a strategic national food security crop in 2012. In 2000, the Fast Track Land Reform Programme completely restructured commercial agriculture and potato farming. A product of the agrarian reforms, the A2- and A1resettlement growers, started growing potato. The A1 resettlement model has individually owned cropping land and shared grazing, while A2 resettlement comprises of self-contained farm units. A survey was conducted to characterise potato growers, mainly to understand the current potato production systems and assess the impact of the landmark reform programme on potato farming. Four production systems, Large-scale commercial, Communal area, A2 resettlement and A1 resettlement, were identified, and two main growing agro-ecological zones, the Highveld and Eastern Nyanga Highlands. In 1961-2013, significant positive trends for annual planted area, average yield and total production were observed. In terms of yield, Zimbabwe is fourth in southern Africa with average yield of $17 \mathrm{t} \mathrm{ha}^{-1}$ in the 2009-2013 period. Large-scale commercial and A2 resettlement systems were well-mechanized and growers owned large land holdings ranging from an average of 165-1,600 ha and 31390 ha across the different areas respectively, with average potato areas of 11 and 8 ha, respectively. A1 resettlement and Communal area growers owned an average of 4 and 3 ha cropping area, respectively, with average potato areas of 0.4 and 1.1 ha, respectively. Input use was significantly different among the production systems. High synthetic fertiliser and biocides use was observed.
\end{abstract}

Key words Irish potato, production systems, agro-ecological zone, input application rate, farm characterisation, Zimbabwe

\section{Introduction}

Irish potato cultivation in contemporary Zimbabwe became well established by the early 1900s (Joyce 1982a). For example, the potato tuber moth, Phthorimaea operculella (Zell.), was recorded and acknowledged as the most troublesome pest of the 1903/04 cropping season (Anonymous 1904). Also Government Notice No. 309 of 1909 outlined regulations affecting the importation of potato in order to prevent the introduction of "Black scab" into the country (Jack 1909). Up to the late 1920s, practically only one variety, Up-to-date, was grown and every year considerable quantities of seed were imported and the first and second harvests were retained for further plantings (Timson 1927). Production was low and only European growers produced potato. In the 1924/25 cropping season, a total of about 1,200 ha were planted and yield was low because a large proportion of growers grew potato to meet requirements on the farm, not applying the best agronomic practices (Bell 1927). In 1956, the 
government started a potato breeding programme and demarcated the potato Quarantine Area and the breeding station at Nyanga Experiment Station (Joyce 1982b). The Quarantine Area is responsible for the initial seed potato multiplication. In the $1960 \mathrm{~s}$, the national breeding programme was authorized to import potato only for breeding and evaluation purposes (Joyce 1982b). Rigid quarantine rules were mandatory in the importation procedures, mainly to protect tobacco production from potential introduction of pests through imported seed potato (Joyce 1982b). Tobacco was a very significant export crop for the country. In 1975, the International Potato Center (CIP) started supplying true seed to the national breeding program (Joyce 1982a). Over 12 cultivars were released since the inception of the national breeding programme making a tremendous impact on potato production in the country (Joyce 1988). Joyce (1988) reported average yields of $15 \mathrm{tha}^{-1}$ in the 1980s up from an average of $9 \mathrm{tha}^{-1}$ in 1960 s, attributed primarily to the success of the breeding program. However, the potato breeding programme has stopped since the turn of the millennium mainly due to the socioeconomic and political problems the country is grappling with.

Total crop output assumed a steady increase trajectory in the 1990s rising to over 40,000 tonnes in 2000 due to constant increases in both cropped area and yield (FAO 2013). The large-scale commercial farming sector dominated potato production then. This farming sector was highly developed, with some of the best infrastructure and farming skills on a comparative basis with most of Africa. Together with smallholder agriculture then, the largescale farmers provided Zimbabwe with the foundation for food security and self-sufficiency that was the envy of a continent dominated by civil wars, poverty and famine. Some of the large commercial farmers of Zimbabwe were 3rd or 4th generations of staying and working the land, acquiring farming experience and skills across the different enterprises (field crops, livestock and horticulture crops including potato) providing Zimbabwe with one of the most developed human resources in Africa (Rukuni and Eicher 1994).

The Fast Track Land Reform Programme (FTLRP) that was initiated in 2000 was a far-reaching directive by the government, that completely restructured commercial agriculture in Zimbabwe and along with it the potato farming systems. A large proportion of the largescale commercial farms were subdivided into smaller units and allocated to new farmers under the A1 and A2 resettlement models. The A1 resettlement model resembles the communal area land allocation system and the beneficiary household was allocated about 6 ha of arable land and communal grazing land. In the A2 resettlement model, beneficiary households were allocated self-contained, small to medium scale farm units for cropping, grazing, residential and woodlots use. Unit sizes under normal circumstances ranged from about 35 ha in the high rainfall regions through 300 ha in the drier parts of the country. Later in the land reform process, larger A2 farms, similar to the large-scale farms of the past, have also been created (Moyo 2011). By 2009, a total of 6,214 farmland properties covering nearly 11 million ha were acquired and allocated to 144,755 households under the A1 resettlement model and to 22,896 households under the A2 resettlement model (MLRR 2009). Fewer than 400 individually owned white farms remained by 2009, from about 4,500 in 1999 (MLRR 2009).

Over a decade after the landmark agrarian reform, it is pertinent to evaluate the productive capacity of the potato land. It becomes even more compelling now because potato is now a declared strategic national food security crop just like maize, the staple crop (The Herald 2012). The potato production systems in the different growing environments in Zimbabwe need to be analysed especially in the context of the seemingly yet to be finalised agrarian reform programme. There is a dearth of information on the impact of the land reform on potato production systems in Zimbabwe. Hence the purpose of this study was to establish and analyse the potato production systems in Zimbabwe and in a way to assess the impact of the FTLRP on production of the crop. Specifically the following issues were considered: (i) 
the natural resource base endowment available to the different production systems or grower categories; (ii) input use in the various agro-ecological environments and production systems; (iii) infrastructure for potato production present; and (v) identification of constraints and possible solutions. Besides eliciting further research questions on potato production in Zimbabwe, an analysis of these important issues will contribute to the growth of the potato industry in the country.

\section{Materials and methods}

(a) Study area and sampling

A comprehensive grower survey was carried out in the period 2011 through 2014. In order to identify the regions currently active in potato production in Zimbabwe, besides literature, the initial port of call were stakeholders already interfacing with growers. These were, among others, the potato seed houses, the government extension agency, research institutions, the government seed services regulatory authority, and farmer organizations. Fig. 1 and Table 1 shows the major potato growing areas in Zimbabwe visited in the grower surveys and the soil sampling sites. The survey locations were the farms/farmers visited and soil samples were collected from the farmers' respective potato lands/farms. 


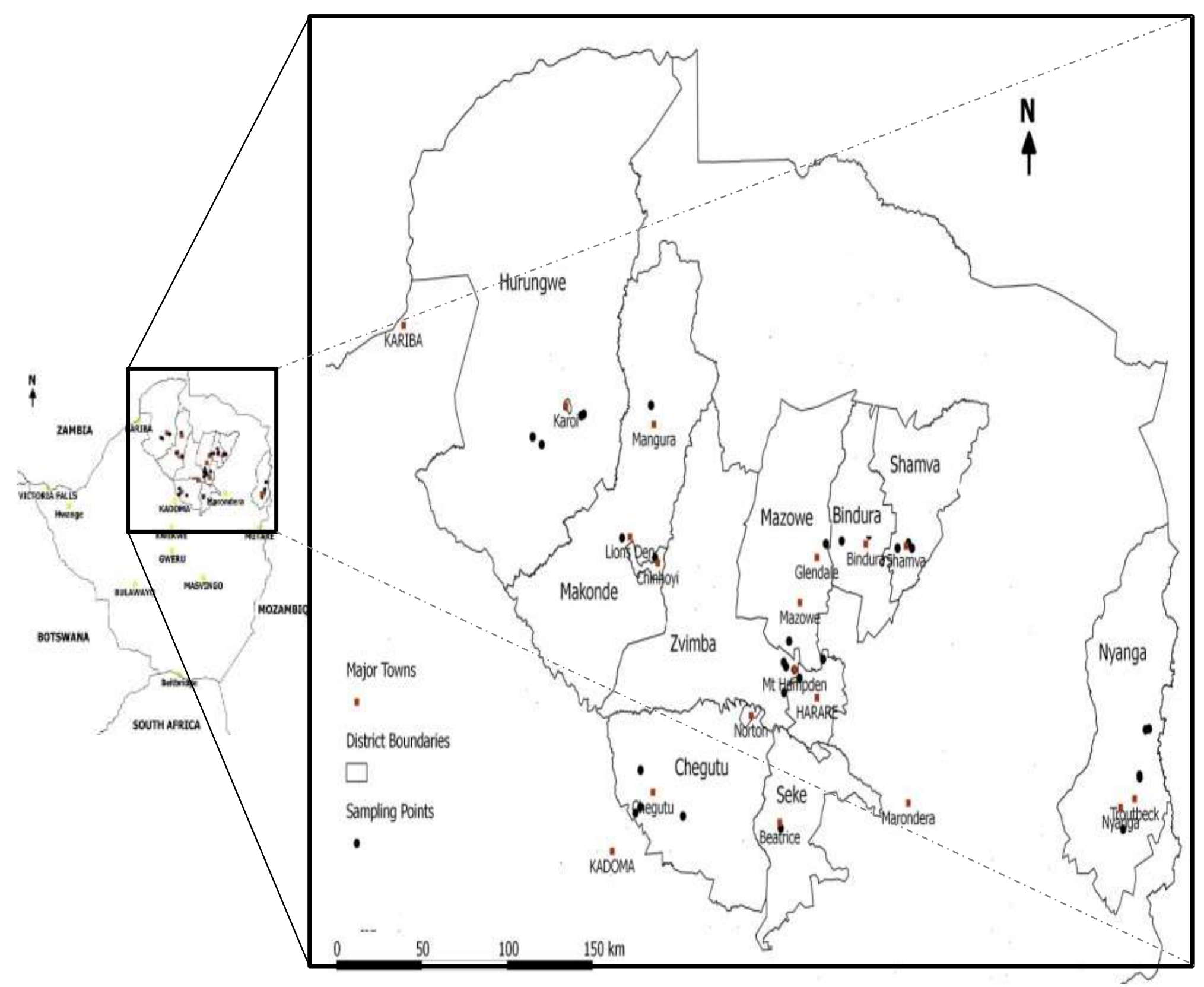

Fig. 1. Map of Zimbabwe indicating the major Irish potato growing districts in which the grower survey and soil sampling was carried out. 


\section{(b) Farmer selection and data collection}

Data were collected on practically all the grower practices in potato production. The sample in each area consisted of growers with a minimum of five continuous years of potato growing experience. Such growers had an established routine practice and a relatively stable input use rate and yield, making the data collected dependable. In many regions, growers with this long experience especially among the recently resettled A1 and A2 farmers were not common. The logistical arrangements were that farmer appointments were made in advance by the government extension agency, AGRITEX (Agricultural, Technical and Extension Services) in each area. The selected growers were visited for the data collection exercise. Stratified random sampling was used for the large number of communal area growers in the Nyanga area (Table 1). Each stratum was a list of growers in one location. Locations with more growers contributed accordingly more growers to the final sample. Using the written list of growers, the AGRITEX officials were given randomly generated numbers between 1 and 10 as the sampled growers. The selected growers from each location made the final list of growers interviewed. In the rest of the areas, the number of growers meeting the minimum of five continuous years potato growing experience was small and all these growers were interviewed (Table 1). Growers selected represented a broad spectrum of gross farm and cropping land sizes, technology use levels and water resources.

The growers sampled included three large-scale commercial (LSC) growers and four A2 resettlement growers from the Quarantine Area located in the Nyanga Eastern Highlands agro-ecological zone. This area is an isolated zone created by a statutory instrument mainly to eliminate Bacterial wilt (Joyce 1982b). It is responsible for the initial potato seed multiplications and only 21 out of the 27 growers in the area are active (Ackerman, personal communication, 2012). A further 18 communal area (CA), 5 A1 resettlement, 5 A2 resettlement and one of the four remaining LSC growers, all outside the Quarantine Area completed the Nyanga Eastern Highlands sample. AGRITEX officials in Nyanga estimated the number of growers to be about $1000 \mathrm{CA}$ and less than $100 \mathrm{~A} 1$ resettlement growers. A total of $11 \mathrm{LSC}$ and $14 \mathrm{~A} 2$ resettlement growers were interviewed in the extensive Highveld agro-ecological zone. According to AGRITEX officials, the Highveld has less than 30 LSC growers and about 100 A2 resettlement growers, while a few A1 resettlement and CA growers are beginning to show interest in potato growing. Table 1 gives an overview of the number of growers interviewed per agro-ecological zone and per production system.

The farming categories in Zimbabwe are well known; these include: large-scale commercial, communal area, A2 resettlement and A1 resettlement. Structural differences separating them are not only land holding, but also other characteristics such as agroecological environment, access to resources and management. For this study, only potatobased production systems (or growers) in these farming categories were targeted. Our paper is a comparative analysis of potato-based production systems in the four farming categories, with potato as the focus crop. 
Table 1. Number of growers per production system interviewed in different areas in the Highveld and Eastern Nyanga Highlands agro-ecological zones of Zimbabwe, in the period 2011-2014.

\begin{tabular}{llcccc}
\hline Agro-ecological zone & Sampling area & \multicolumn{3}{c}{ Production system } \\
\cline { 3 - 5 } & & Large-scale commercial & A2 resettlement & A1 resettlement & Communal area \\
\hline Eastern Nyanga Highlands & Nyanga Quarantine Area & 3 & 4 & 0 & 5 \\
& Nyanga district* & 1 & 5 & 0 & 0 \\
\multirow{3}{*}{ Highveld } & Harare & & & 0 & 0 \\
& Bindura & 5 & 2 & 0 & 0 \\
& Chegutu & 2 & 2 & 0 & 0 \\
& Chinhoyi & 2 & 2 & 0 & 0 \\
& Karoi & 1 & 3 & 0 & 0 \\
\hline
\end{tabular}

*Excluding the Quarantine area 
Table 2 summarizes the questions asked in the interviews. The growers and/or their respective operations managers could easily respond to the questions regarding land property sizes, water resources, water application rates and irrigation frequencies.

Table 2. Summary of the grower survey.

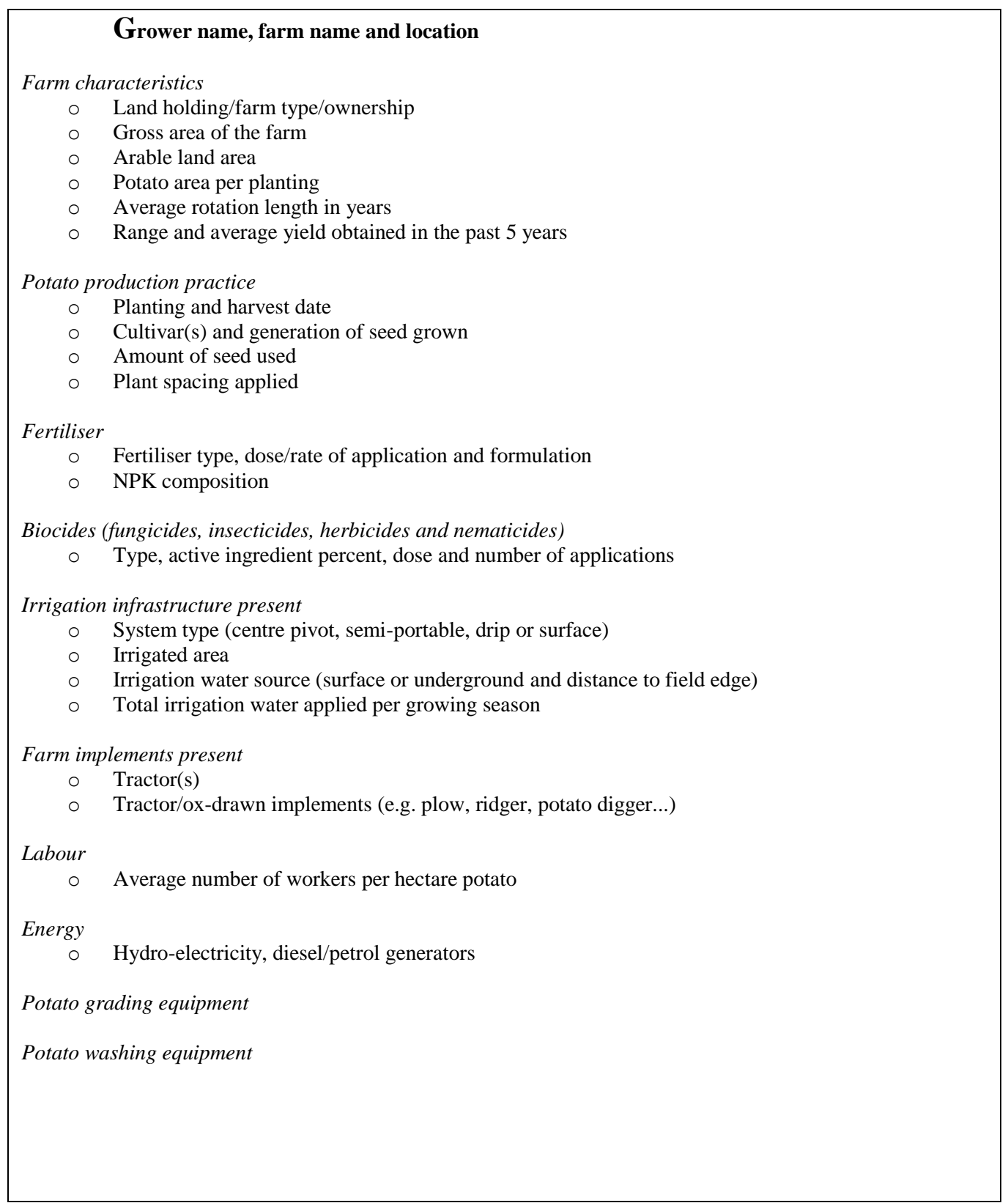

For the other questions on yield, fertiliser, labour and biocide application rates, the growers referred to their records. Some growers kept these and also rainfall records spanning more than 10 years, which could be a testimony to the training role of AGRITEX. For especially fungicide and pesticide type, dose and frequency of applications, the grower's responses were checked against the labels on the chemical packaging from the respective agro-chemical companies.

Soil samples from the upper $20 \mathrm{~cm}$ were taken for analyses, mainly $\mathrm{pH}$, texture and NPK. The samples were taken from the fallow potato fields in which the grower wanted to 
plant the next potato crop. The analysis results could help understand the textural class growers preferred for potato growing and the general soil fertility management by the growers. Data on input application rates were used to analyse the variation across agroecological environments and production systems of the grower. Mineral fertiliser application rates were also compared against those used by growers in the neighbouring countries. The input use data were also used together with the farm features and infrastructure for potato production present to characterise the potato production systems in Zimbabwe.

Growers were asked which potato cultivars they grew in an attempt to assess their preference of potato cultivars. For the sampled growers in each location studied, the number of growers using a specific cultivar was recorded. This enabled the computation of the percent growers using the particular cultivar.

Long term meteorological data were purchased from the Meteorological Services Department (MSD) and they were used to characterise the agro-ecological conditions of the main growing areas.

Data on area, output and yield were obtained from various sources such as from literature, FAO, the Central Statistics Office, CSO (now ZIMSTAT), and from the farmer interviews. The data were used to discuss the development trajectory of the Zimbabwe potato crop in recent years. Factors constraining production were identified both from literature and the grower interviews.

\section{(c) Data analysis}

Data were subjected to analysis of variance (ANOVA) using the GenStat $16^{\text {th }}$ edition statistical package (VSN International, 2011). All the mean values of the input use rates in the different production systems identified under the different agro-ecological regions were tested for significant differences using the F-test at 5\% level. The mean values of the input use rates were separated using the least significance difference (LSD) test at 5\% level where the F-test showed significant effects.

\section{Results and discussion}

Annual potato area, output and yield in Zimbabwe

Since the beginning of potato farming in the early 1900s, the area increased 4-fold from about 600 ha in 1926 to over 2,400 ha in 1961 (Bell 1927; FAO 2013). The trend of annual average yield, planted area and total annual production was positive for the period 1961 to 2013 though with notable annual variation (Fig. 2). Total crop production increased steadily to over 40,000 tonnes in 1989 due to constant increases in both cropped area and yield (Figs 2B and 2C). For annual planted area, average yield and total production, the positive trend was significant (Fig. 2). Since 2009, a steady increase in annual potato production was realised mainly due to expansion in potato planting area (Figs 2B and 2C). Probably, the stable socioeconomic and political environment brought about by the Government of National Unity (GNU) in 2009 created a conducive environment for both production and consumption of potato. 


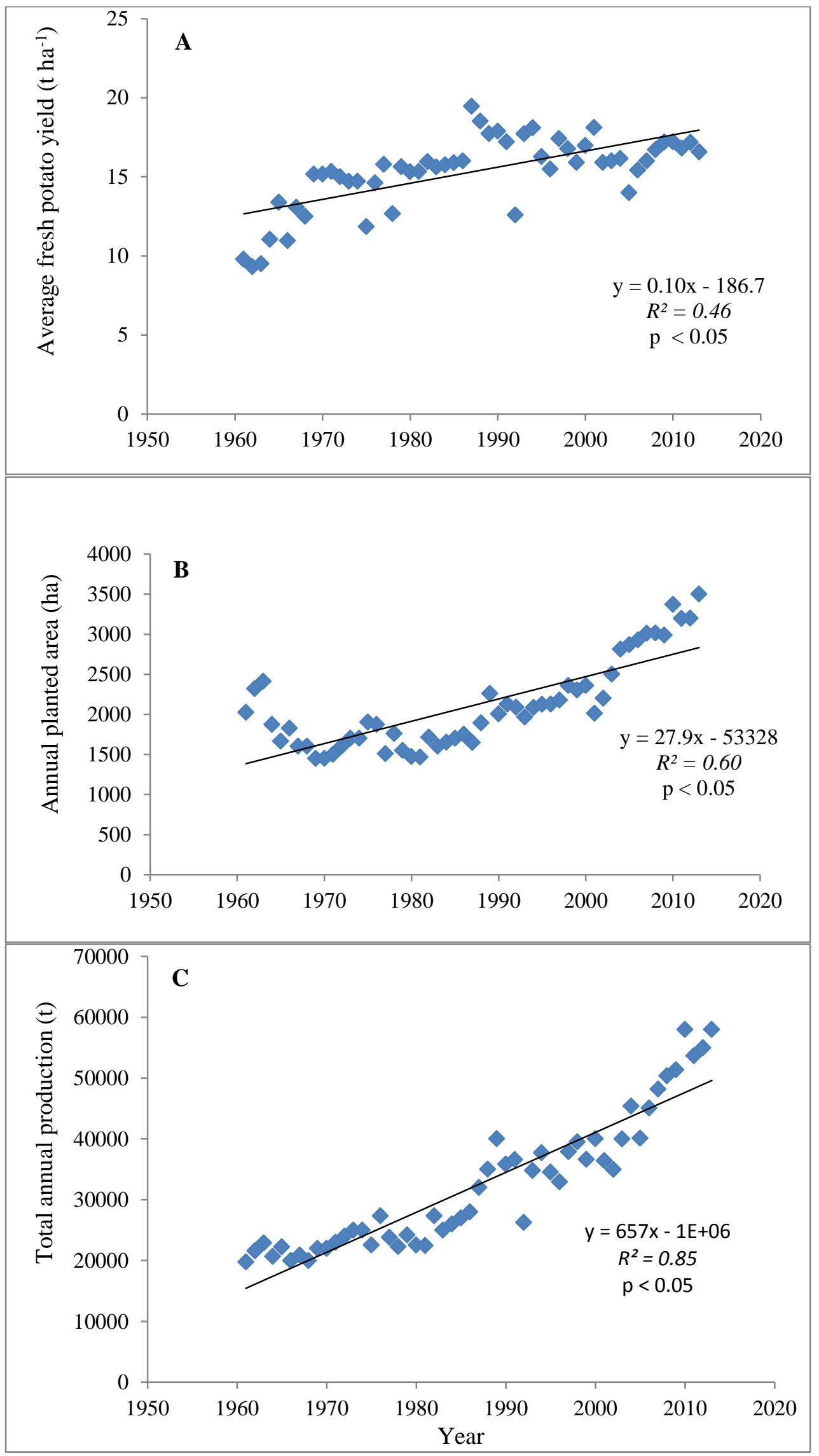

Fig. 2. Development trend of fresh tuber yield (A), area planted (B) and total fresh tuber production (C) of Irish potato during the period 1961 to 2013 in Zimbabwe (CSO 1993, 1996, 1999, 2001, 2002; FAO 2013). 
In 2013, production reached a peak of 58,000 tonnes from a cropping area of 3,500 ha, both records being the highest ever reached. The country aims to plant 30,000 ha potato annually (Ackerman K, personal communication, 2013; The Herald 2011). This target is based on market potential projections sufficient to absorb more plantings and the assertion by the seed houses that they have the potential to produce enough seed for this area (The Herald 2011). In 2010, the government banned the importation of potato mainly to protect local growers (Dube 2013). However smuggling of potato from South Africa into the south-western parts of the country is still being reported (Chimoio 2013). The current potato grower base of the country is, however, limited to a few remaining white LSC farmers and A2 resettlement farmers. Only Nyanga district, a traditional potato growing area, has in addition A1 resettlement and CA farmers.

At the regional level, Zimbabwe is in eighth position out of 10 selected countries in sub-Saharan Africa, in terms of the average annual potato area planted in the period 20092013 (Fig. 3c; FAO 2013).

(a)

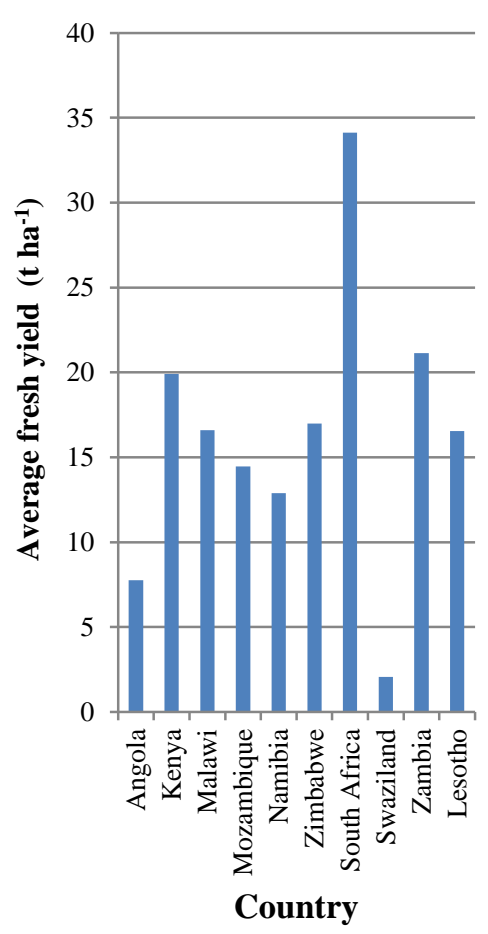

(b)

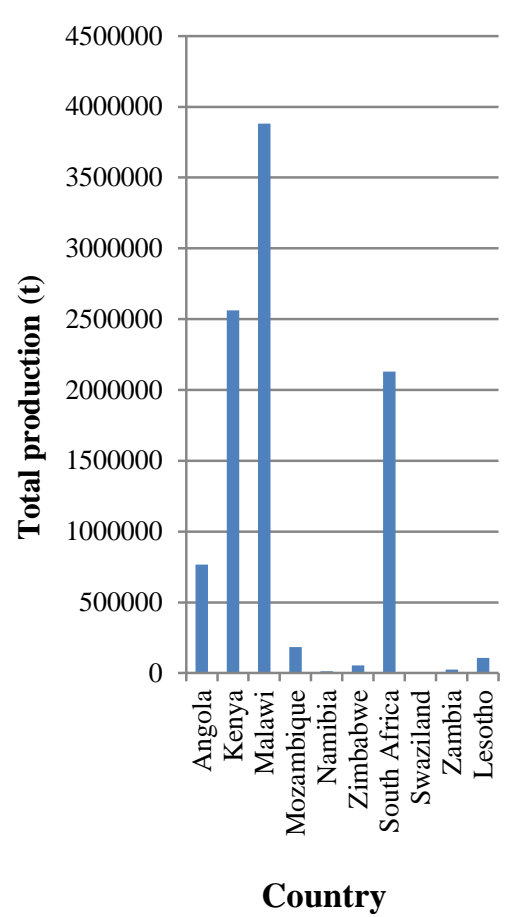

(c)

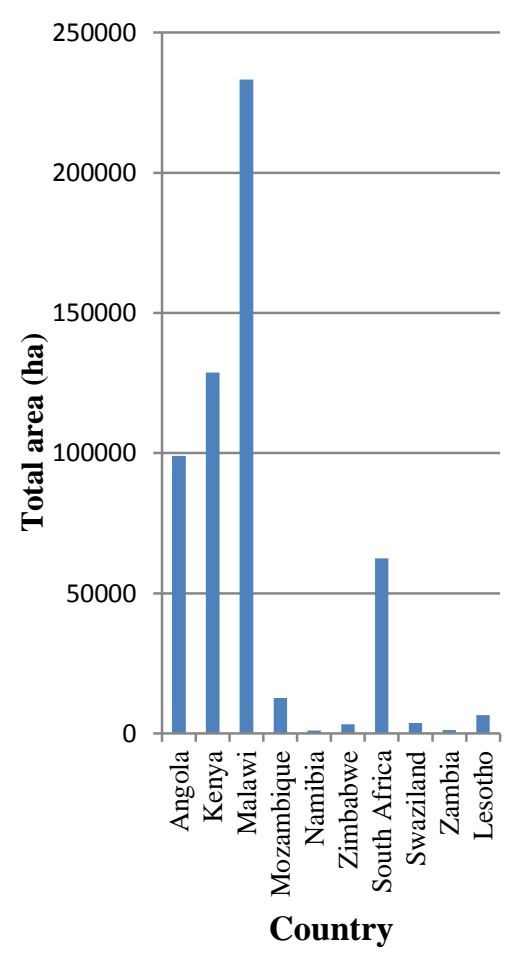

Fig. 3. Average yield (a), total production (b) and total area (c) of fresh potato tuber as annual averages for the period 2009-2013 of selected countries in sub-Saharan Africa (FAO 2013).

In terms of yield, Zimbabwe is fourth out of these 10 regional countries with an average annual yield of $17 \mathrm{t} \mathrm{ha}^{-1}$ in the period 2009-2013 (Fig. 3a; FAO 2013). This may imply that for a sustained growth in potato production, the country should focus on increasing the grower base, especially among the smallholder sector. Concurrently, there may be room to increase potato yield through improving resource use efficiencies, particularly of synthetic fertilisers. In addition, improving water management, pest and disease control, use of high 
yielding cultivars, and use of certified seed may improve production efficiency. Probably profitability of the potato enterprise may increase from the current state. Smallholder growers sampled cited high costs of potato production, especially of seed and fertiliser, as a constraining factor. An article by a local daily newspaper quoted beneficiaries of the land reform programme producing potato expressing concern over high costs of production (The Herald 2011). This, the growers say, was making it difficult for resource-poor but interested growers to break into the sector (The Herald 2011). Commercial potato farming in Zimbabwe is capital intensive. Computations of the variable costs of potato production range from about 2,000 to 7,000 USD per ha with seed contributing between 28 and $47 \%$ of the total variable costs. Interest to produce potato is huge but is restricted by the high production costs coupled by the more than decade long economic malaise from which the country has yet to emerge (The Herald 2011; Manzira C, personal communication, 2013). Hence recent calls to encourage smallholder farmers to take up potato production were made (USAID 2013).

\section{Potato production systems in Zimbabwe: production zones}

Two production/agro-ecological zones were distinguished: (i) the Eastern Nyanga Highlands at elevations above $1,800 \mathrm{~m}$ amsl (above mean sea level) and (ii) the Highveld region at altitudes of 1,200 to 1,800 m amsl. The Eastern Highlands agro-ecological zone in Nyanga district hosts the government breeding activities at the Nyanga Experiment Station and the initial seed multiplication in the Quarantine Area. Multiplication of seed potato is in two stages. First, foundation seed undergoes three multiplications to produce grade AA1 through AA3 seed. This is done in a designated quarantine area in Nyanga district at altitudes above $1,800 \mathrm{~m}$ amsl. One crop is produced each year under rain-fed conditions with plantings usually in November at the onset of the spring rains. Growers here receive virus-free seed tubers from the government breeding programme and carry out three multiplications, foundation seed through class AA3 (Joyce 1982b). This area must be completely free of other solanaceous plants. The seed potato is grown rain-fed because of the risk of Bacterial wilt from the soil-borne bacterium Ralstonia solanacearum from irrigation water sediments. This is basically the reason growers here do not have irrigation systems (Ackerman $\mathrm{K}$, personal communication, 2012). Class AA3 seed then leaves the quarantine area and goes to the Highveld for further multiplication into class A1 through A3 and all of A1, A2 and A3 class seed is used for ware potato production.

Outside the Quarantine Area in the Eastern Highlands, ware potato production activities are carried out by LSC, CA, A1 and A2-resettlement growers. Generally the soils range from sand to sandy clay, with clay content ranging from 6 to 52\% (Tables S1 and S2 in Supplementary material). The lowest mean monthly minimum temperature recorded in Nyanga was $5.2{ }^{\circ} \mathrm{C}$ in July and the highest long term mean monthly maximum temperature was $23.2{ }^{\circ} \mathrm{C}$ in November (Table S3). The Eastern Highlands receives rainfall throughout the year. Long term mean monthly rainfall is about $114 \mathrm{~mm}$ and it ranges from about $14 \mathrm{~mm}$ in August to about $340 \mathrm{~mm}$ in January (Table S3). In terms of rainfall and temperature regimes, the Eastern Highlands provides the best agro-ecological environment for potato production in Zimbabwe. For example, the cool temperatures, dry soils, and isolation from viruses allow AA seed to remain in the ground up to July after maturing in March without any loss of yield or quality (Joyce 1982b). Following harvest, the tubers are stored in well ventilated sheds without refrigeration. The rising temperatures in August and September enable the tubers to break dormancy and such tubers are well-sprouted and in excellent condition for planting in November (Joyce 1982b). In the Eastern Highlands, ware potato production is year round 
where there is supplementary irrigation during the dry months, hence the potato spends little time in storage.

The Highveld agro-ecological zone is much wider in areal extent and includes the Harare, Bindura, Chegutu, Chinhoyi and the Karoi regions (Fig. 1). There is also a wide variation in the predominant weather (Table S1) and soil conditions (Tables S4, S5 and S6). The lowest mean monthly minimum temperature was $7.1^{\circ} \mathrm{C}$ in July and the highest long term mean monthly maximum temperature was $31.7{ }^{\circ} \mathrm{C}$ in October (Tables S4, S5 and S6). Soils are generally clay loams. Long term average annual rainfall ranges from about $800 \mathrm{~mm}$ in the Chinhoyi region to about $830 \mathrm{~mm}$ in the Harare region. In the Highveld areas, besides the summer crop of November through March/April, two additional crops are grown under irrigation in early and late winter. The first irrigated crop is planted from as early as the end of January commencing growth with the last rains and is irrigated from April or May until harvest in June/July (Timson 1946; Joyce 1982a). Planting of the second irrigated crop takes place in the middle of the dry season in June/July but can be delayed until early August in frost prone areas (Timson 1946). Harvest of the second crop is in November/December and is often hindered by wet conditions due to the onset of the rainy season (Joyce 1982a).

\section{Potato production systems in Zimbabwe: land characteristics}

A total of four potato production systems were identified in the major potato growing areas of Zimbabwe (Tables 3 and 4). These were the large-scale commercial (LSC), communal area (CA), A1 and A2 resettlement production systems. The LSC holdings had an average farm gross land size ranging from 165 to 1,600 ha, varying with the area and the agro-ecological zones (Tables 3 and 4). Average farm cropping area in the LSC production systems ranged from 17 to 900 ha and the average potato area per planting per farm was 11 ha and ranged from 3 to 25 ha. Due to the large holdings available, the LSC growers could all practice a minimum of 3 years potato rotation against a general recommendation of a minimum of 4 years.

In the A2 resettlement production system, growers sampled in different areas had an average gross land size ranging from 31 to 390 ha across areas whereas the average cropping area ranged from 16 to 313 ha. The average potato area per planting was 8 ha and ranged from 1 to 23 ha, and a minimum 3 year potato rotation was practiced.

The A1 resettlement and CA production systems were only identified in the Eastern Highlands Nyanga agro-ecological zone. Cropping area averaged 4 and 3 ha in the A1 resettlement and CA production systems respectively; whereas the average potato area per planting was 0.4 and 1.1 ha respectively. Both production systems practised 1-year potato rotation probably due to the limitations of cropping land available. The Quarantine Area was comprised of the LSC and A2 resettlement production systems only. Growers sampled here had average gross land sizes ranging from 147 to 347 ha and an average cropping area of 82 and 111 ha for A2 resettlement systems and LSC systems, respectively. The average potato area per planting was 17 and 25 ha for the respective systems, and growers practised a minimum 3-year rotation system (Table 4). 
Table 3. Farm characteristics, farm equipment and irrigation resources inventory of Irish potato growers in different areas in the Highveld agroecological zone of Zimbabwe, based on interviews in the period $2011-2014$.

\begin{tabular}{|c|c|c|c|c|c|c|c|c|c|c|}
\hline \multirow[t]{2}{*}{ Characteristic } & \multicolumn{2}{|c|}{ Harare } & \multicolumn{2}{|c|}{ Bindura } & \multicolumn{2}{|c|}{ Chegutu } & \multicolumn{2}{|c|}{ Chinhoyi } & \multicolumn{2}{|c|}{ Karoi } \\
\hline & $\mathrm{LSC}$ & A2 & $\mathrm{LSC}$ & $\mathrm{A} 2$ & $\mathrm{LSC}$ & A2 & $\mathrm{LSC}$ & A2 & $\mathrm{LSC}$ & A2 \\
\hline \multicolumn{11}{|l|}{ Farm characteristics } \\
\hline Land holding/type [number of growers sampled] & 5 & 2 & 2 & 5 & 2 & 2 & 1 & 2 & 1 & 3 \\
\hline Average farm total size [ha] & 190 & 31 & 1600 & 236 & 221 & 305 & 500 & 390 & 400 & 149 \\
\hline Average cropping area [ha] & 131 & 23 & 900 & 172 & 95 & 74 & 105 & 313 & 280 & 108 \\
\hline Average potato planting area per planting [ha] & 15 & 3 & 7 & 7 & 3 & 1 & 10 & 23 & 10 & 4 \\
\hline Average rotation length [years] & 3 & 3 & 4 & 3 & 3 & 2 & 2 & 3 & 3 & 4 \\
\hline \multicolumn{11}{|l|}{ Irrigation characteristics } \\
\hline Irrigation facilities present [growers in sample] & 5 & 2 & 2 & 5 & 2 & 2 & 1 & 2 & 1 & 2 \\
\hline Average total area irrigated [ha] & 101 & 8 & 180 & 113 & 15 & 59 & 18 & 33 & 10 & 27 \\
\hline Centre pivot systems [growers in sample] & 1 & 0 & 1 & 0 & 0 & 1 & 0 & 2 & 1 & 0 \\
\hline Semi-portable systems [growers in sample] & 4 & 2 & 2 & 5 & 2 & 2 & 1 & 1 & 1 & 2 \\
\hline Hydro-electricity energy [growers in sample] & 5 & 2 & 2 & 5 & 2 & 2 & 1 & 2 & 1 & 2 \\
\hline Diesel irrigation energy [growers in sample] & 1 & 0 & 1 & 0 & 1 & 0 & 1 & 1 & 1 & 2 \\
\hline Surface irrigation water [growers in sample] & 0 & 0 & 2 & 3 & 0 & 1 & 0 & 1 & 1 & 2 \\
\hline Ground irrigation water [growers in sample] & 5 & 2 & 0 & 2 & 2 & 1 & 1 & 1 & 0 & 0 \\
\hline \multicolumn{11}{|l|}{ Equipment Ownership [growers in sample] } \\
\hline Cold room facilities & 3 & 0 & 0 & 0 & 0 & 0 & 0 & 0 & 0 & 0 \\
\hline
\end{tabular}

Note: LSC = Large Scale Commercial, A2 = A2 Resettlement. All the sampled growers have ownership of at least one tractor and equipment for land preparation, planting, spraying and potato harvesting; none of the growers had potato washing equipment. Some growers owned both centre pivots and semi-portable irrigation systems. Stand-by generators (diesel driven) were used during power outages. 
Table 4. Farm characteristics, farm equipment and irrigation resources inventory of Irish potato growers in the Eastern Nyanga Highlands agroecological zone of Zimbabwe, based on interviews in the period $2011-2014$.

\begin{tabular}{|c|c|c|c|c|c|c|}
\hline \multirow{2}{*}{ Characteristic } & \multicolumn{4}{|c|}{ Nyanga district (excluding Quarantine area) } & \multicolumn{2}{|c|}{ Quarantine area } \\
\hline & $\begin{array}{l}\text { Large-scale } \\
\text { commercial }\end{array}$ & $\begin{array}{c}\mathrm{A2} \\
\text { resettlement }\end{array}$ & $\begin{array}{c}\mathrm{A1} \\
\text { resettlement }\end{array}$ & $\begin{array}{c}\text { Communal } \\
\text { area }\end{array}$ & $\begin{array}{l}\text { Large-scale } \\
\text { commercial }\end{array}$ & $\begin{array}{c}\mathrm{A2} \\
\text { resettlement }\end{array}$ \\
\hline \multicolumn{7}{|l|}{ Farm characteristics } \\
\hline Land holding/farm type [number of growers sampled] & 1 & 5 & 5 & 18 & 3 & 4 \\
\hline Average farm total size [ha] & 165 & 59 & 4 & 3 & 347 & 147 \\
\hline Average cropping area [ha] & 17 & 16 & 4 & 3 & 111 & 82 \\
\hline Average potato planting area per planting [ha] & 7.5 & 3.3 & 0.4 & 1.1 & 25 & 17 \\
\hline Average rotation length [years] & 4 & 2 & 1 & 1 & 4 & 3 \\
\hline \multicolumn{7}{|l|}{ Irrigation characteristics } \\
\hline Growers with irrigation facilities [number out of growers sampled] & 1 & 5 & 4 & 16 & 0 & 0 \\
\hline Average total area irrigated [ha] & 22 & 5.9 & 0.4 & 1.2 & 0 & 0 \\
\hline Centre pivot irrigation system [number out of growers sampled] & 0 & 0 & 0 & 0 & 0 & 0 \\
\hline Semi-portable irrigation system [number out of growers sampled] & 1 & 5 & 4 & 16 & 0 & 0 \\
\hline Hydro-electricity energy source [number out of growers sampled] & 1 & 1 & 0 & 0 & 0 & 0 \\
\hline Diesel energy source [number out of growers sampled] & 0 & 2 & 0 & 0 & 0 & 0 \\
\hline Gravity [number out of growers sampled] & 0 & 2 & 4 & 16 & 0 & 0 \\
\hline Surface irrigation water source [number out of growers sampled] & 1 & 5 & 4 & 16 & 0 & 0 \\
\hline Under-ground irrigation water source [number out of growers sampled] & 0 & 0 & 0 & 0 & 0 & 0 \\
\hline \multicolumn{7}{|l|}{ Machinery/Implements Ownership [ growers in sample] } \\
\hline Tractors & 1 & 2 & 0 & 0 & 3 & 4 \\
\hline Potato grading equipment & 1 & 0 & 0 & 0 & 3 & 4 \\
\hline Cold room facilities & 1 & 0 & 0 & 0 & 0 & 0 \\
\hline
\end{tabular}

Note: all the sampled growers owned equipment for land preparation, planting, spraying and harvesting. None had potato washing equipment. 
Potato production systems in Zimbabwe: mechanisation and irrigation characteristics

All the growers sampled from the LSC and A2 resettlement production systems in the Highveld had irrigation facilities used for the early and late winter potato crop (Table 3 ). Karoi region was the exception with one out of the three A2 resettlement growers interviewed without irrigation facilities. The average irrigated area the LSC and A2 resettlement production systems across all areas in the Highveld were in the range $8-180$ ha, and both pivot and semi-portable irrigation systems were available. All the irrigating growers had grid hydro-electricity energy for the irrigation systems and some had standby diesel generators for use during power outages. Most of the growers used the ground water source for their irrigation systems. Similarly, all the sampled growers in the LSC and A2 resettlement production systems owned at least one tractor and equipment for land preparation, planting, spraying and potato harvesting. None though had potato washing equipment but three out of the five $(60 \%)$ growers sampled from the LSC sector in the Harare area had cold room facilities. This high level of mechanised potato production creates an impression, particularly among smallholder farmers, that this high level of mechanisation is a prerequisite before the crop can be produced.

In the Eastern Highlands Nyanga district, similarly all LSC and A2 growers interviewed had irrigation systems, here drawing water from surface water sources (Table 4). The average irrigated area ranged from 0.4 ha in the A1 resettlement systems to 22 ha in the LSC systems (Table 4). In the A1 resettlement and CA production systems, the majority of growers interviewed had irrigation facilities (Table 4). Both production systems had semiportable irrigation designs and all were gravity fed giving the growers a huge saving on irrigation energy costs. In terms of mechanisation, all the LSC growers in Nyanga owned at least one tractor and equipment for land preparation, planting, spraying, harvesting and potato grading. The growers in the CA, A1 and some A2 resettlement production systems also had animal-drawn equipment for potato production.

Growers applied varying amounts of irrigation water across the different production systems (Table 5). The irrigation water quantities applied per ha were significantly different $(\mathrm{p}<0.001)$ among the production systems (Table 5). Lowest average irrigation water use (213 $\mathrm{mm})$ was in the A1 resettlement production systems, all located in the Nyanga Eastern Highlands. The humid and high rainfall conditions experienced there (Table S3) decreased the need for supplemental irrigation. However, the high average irrigation application amount observed $(736 \mathrm{~mm})$ in the CA system, also all located in the Nyanga Eastern Highlands was unexpected. This was explained by the fact that the majority of the CA growers' irrigation systems were gravity-fed, hence the tendency to over-irrigate. This practice of over-irrigating is common where adequate irrigation water is easily available or the energy cost is minimal. For example, in Chile, Haverkort et al. (2014) reported that growers applied twice the amount of the calculated water need.

The majority of A2 resettlement and LSC growers were located in the Highveld agroecological zone and their average supplementary irrigation water use was 465 and $549 \mathrm{~mm} \mathrm{ha}^{-}$ ${ }^{1}$ respectively (Table 5). The Highveld region experiences a tropical climatic pattern, with a distinct summer rainfall and dry winter season (Tables S4, S5 and S6). Hence, supplementary irrigation becomes necessary for the winter potato crop. As already alluded to, the first irrigated (early winter) crop is normally planted in January, commencing growth with the last summer rains, and is irrigated from April until harvest in June/July (Timson 1946; Joyce 1982a). Planting of the second irrigated (late winter) crop takes place in the middle of the dry season in June/July and the crop is harvested in November/December. The onset of the rainy season in November/December reduces the need for supplementary irrigation. 


\section{Fertiliser application rates}

All of the N, P and K nutrient levels used were significantly different $(\mathrm{p}<0.05)$ across all production systems (Table 5). The average mineral fertiliser application rate among all the sampled growers was $178 \mathrm{~kg} \mathrm{~N} \mathrm{ha}^{-1}, 275 \mathrm{~kg} \mathrm{P}_{2} \mathrm{O}_{5} \mathrm{ha}^{-1}$ and $186 \mathrm{~kg} \mathrm{~K}_{2} \mathrm{O} \mathrm{ha}^{-1}$ which was way above the general recommended NPK rates in neighbouring countries. For example, the general recommended rates in Kenya were $90 \mathrm{~kg} \mathrm{~N} \mathrm{ha}^{-1}$ and $230 \mathrm{~kg} \mathrm{P}_{2} \mathrm{O}_{5}$ ha $^{-1}$ (Kaguongo et al. 2008); in South Africa $170 \mathrm{~kg} \mathrm{~N} \mathrm{ha}^{-1}, 160 \mathrm{~kg} \mathrm{P}_{2} \mathrm{O}_{5} \mathrm{ha}^{-1}$, and $120 \mathrm{~kg} \mathrm{~K}_{2} \mathrm{O} \mathrm{ha}^{-1}$ (FAO 2005) and in Ethiopia $110 \mathrm{~kg} \mathrm{~N} \mathrm{ha}^{-1}, 40 \mathrm{~kg} \mathrm{P}_{2} \mathrm{O}_{5} \mathrm{ha}^{-1}$, and $100 \mathrm{~kg} \mathrm{~K}_{2} \mathrm{O} \mathrm{ha}^{-1}$ (Haile and Mamo 2013). Both the LSC and A2 resettlement production systems used higher nutrient application rates than the smallholder A1 resettlement and CA systems (Table 5). General fertiliser recommendation for potato production in Zimbabwe is 120,280 and $180-240 \mathrm{~kg} \mathrm{ha}^{-1}$ of N, $\mathrm{P}_{2} \mathrm{O}_{5}$ and $\mathrm{K}_{2} \mathrm{O}$, respectively (FAO 2006). The LSC and A2-resettlement systems had a tendency to apply rates exceeding the general recommendations. Probably this caters for micro-climate and soil differences or is an insurance in the absence of soil analysis, since more than $95 \%$ of the sampled growers did not have soil tests to determine $\mathrm{pH}$ and inherent soil fertility levels.

In the LSC production system, no significant relationships were observed between actual potato yield and the NPK nutrient application rates (Fig 4). This probably suggests that generally the nutrient use levels in the LSC production system had approached a ceiling determined by the yield potential of the cultivars grown. From this relationship (Fig. 4), it is most likely that fertiliser application rate is probably one of the least likely causes of low potato yields in the LSC production system. Actually, there is a real danger of overfertilisation in the LSC production system and the potential for losses into the environment. Recently, studies on wheat production in many regions of China have observed overapplication of fertilisers which led to increases in both residual nutrients and the potential for losses into the environment (Chuan et al. 2013). Growers in the LSC production systems need to focus on other limiting crop management aspects to improve fertiliser use efficiency of potato and thereby increase yield while reducing the fertiliser application rates. Lassaletta et al. (2014) demonstrated that it is possible to move the fertiliser-yield relationship to a more efficient level through shifting yield upwards. Such management interventions include better nutrient management, micro-nutrient amendments, high-yielding cultivars, water management, pest and disease management (Conant et al. 2013; Sutton et al. 2013). Growers in Zimbabwe are still using old cultivars of the 1980s and early 1990s due to the slowing down of the national breeding programme (Manzira C, personal communication, 2014). Significant positive relationships were observed between actual potato yield and the nutrient application rate in the CA, A2 resettlement and A1 resettlement production systems (Fig. 4). Notably, the gradients of the nutrient use-yield relationship in the CA production system were the largest compared to other production systems (Fig. 4). The least gradient was observed in the nutrient use-yield relationship of the LSC production system (Fig. 4). Hence, this indicates that the highest yield response to nutrient use was in the CA production system and that the least response was in the LSC production system. This implies that yield benefits can be realised in the CA systems through increasing nutrient use, especially, potassium, $\mathrm{K}_{2} \mathrm{O}$. However, the option of increasing nutrient use is untenable in the short to medium term in Zimbabwe. The cost of synthetic fertilisers is high, and the harsh macro-economic conditions currently obtaining in the country worsen the situation particularly of resource-constrained smallholder production systems. The remaining option of other cultural practices already alluded to needs to be explored. 
Table 5. Mean values of input application rates used in fresh Irish potato growing by the different production systems in the major potato farming areas of Zimbabwe, 2011-2014.

\begin{tabular}{|c|c|c|c|c|c|c|c|c|c|}
\hline \multirow[t]{2}{*}{ Production system } & \multirow[t]{2}{*}{$\begin{array}{l}\text { Yield } \\
{\left[\mathrm{t} \mathrm{ha}^{-1}\right]}\end{array}$} & \multicolumn{3}{|c|}{$\begin{array}{l}\text { Biocides } \\
{\left[\text { g a.i. } \text { ha }^{-1}\right]}\end{array}$} & \multicolumn{3}{|c|}{$\begin{array}{l}\text { Nutrients } \\
{\left[\mathrm{kg} \mathrm{ha}^{-1}\right]}\end{array}$} & \multirow[t]{2}{*}{$\begin{array}{c}\text { Irrigation water } \\
{\left[\mathrm{mm} \mathrm{ha}^{-1}\right]}\end{array}$} & \multirow[t]{2}{*}{$\begin{array}{c}\text { Seed } \\
{\left[\mathrm{kg} \mathrm{ha}^{-1}\right]}\end{array}$} \\
\hline & & Fungicides & Insecticides & Herbicides & $\mathbf{N}$ & $\mathbf{P}_{2} \mathbf{O}_{5}$ & $\mathrm{~K}_{2} \mathrm{O}$ & & \\
\hline A 2 resettlement & $23 \mathrm{~b}$ & $38684 \mathrm{a}$ & $1454 \mathrm{~b}$ & 2033 & $197 \mathrm{a}$ & $270 \mathrm{a}$ & $218 \mathrm{a}$ & $465 \mathrm{~b}$ & 2199 a \\
\hline A1 resettlement & $8 \mathrm{~d}$ & $18320 \mathrm{~d}$ & $1015 \mathrm{~d}$ & na & $94 \mathrm{c}$ & $91 \mathrm{c}$ & $90 \mathrm{c}$ & $213 \mathrm{c}$ & $990 \mathrm{c}$ \\
\hline F pr. & $*$ & $* *$ & $* *$ & $\mathrm{~ns}$ & $*$ & $*$ & $* *$ & $* *$ & $* *$ \\
\hline LSD & 5 & 3664 & 185 & 70 & 26 & 50 & 35 & 107 & 309 \\
\hline CV $(\%)$ & 36 & 17 & 18 & 4 & 24 & 33 & 27 & 27 & 25 \\
\hline
\end{tabular}

Key: a.i. $=$ active ingredient, na $=$ not applicable, $*$ denotes significant difference at $\mathrm{p}<0.05, * *$ denotes significance at $\mathrm{p}<.001$, ns denotes non-significance at $\mathrm{p}<0.05$, mean values in the same column followed by the same letter are not significantly different 

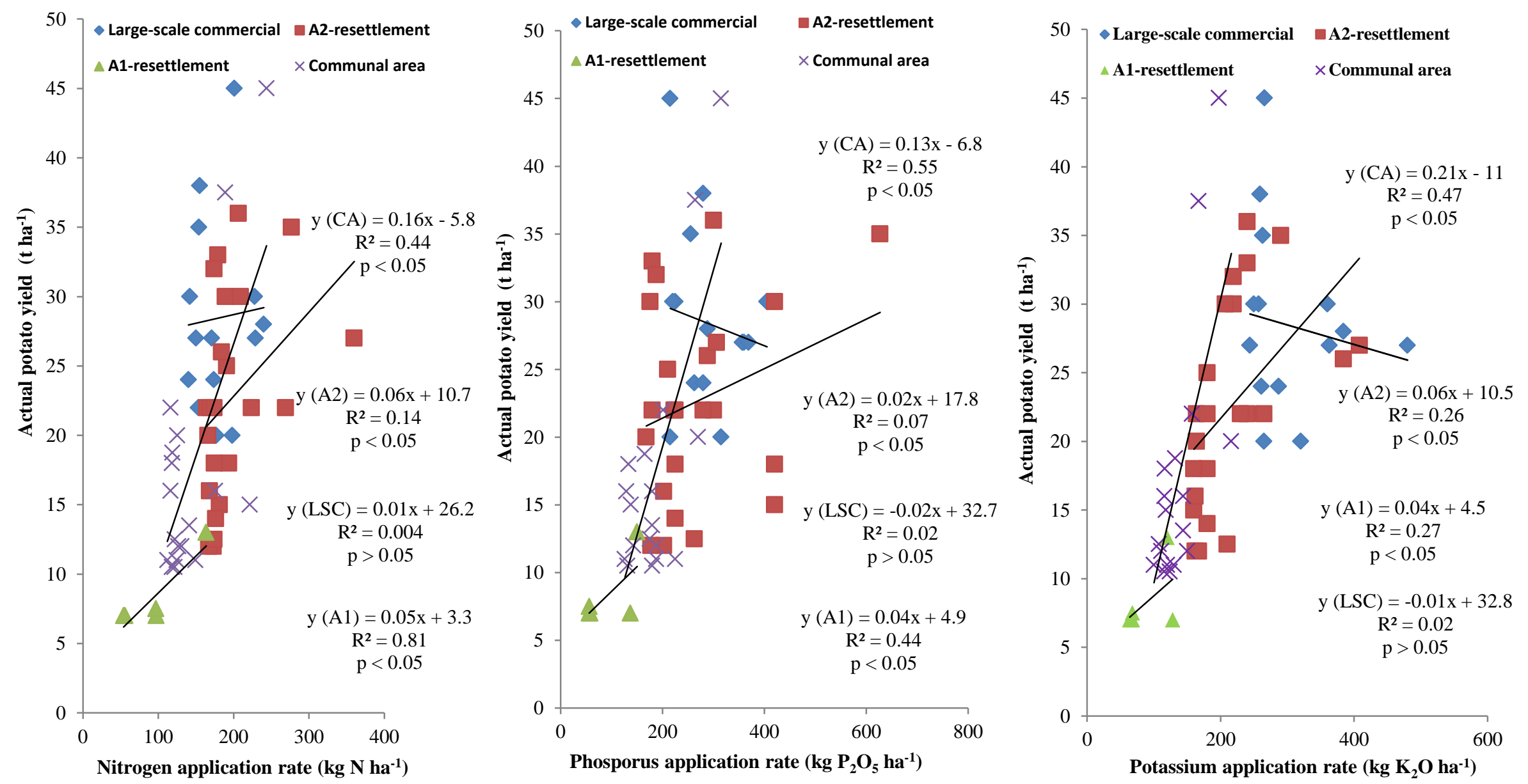

Fig. 4. Relationship between nutrient application rate and actual potato yield in the different potato production systems in Zimbabwe. 


\section{Biocide application rates}

Fungicides were by far the most frequently used biocide in potato production across all the production systems in Zimbabwe (Table 5). Early blight (Alternaria solani), because of the favourable climatic conditions for it, was more common and problematic than late blight (Phytophthora infestans) and other fungi (Manzira 2010). Both fungicide and insecticide use was significantly different $(\mathrm{p}<0.001$ ) among the production systems (Table 5). The LSC and A2 resettlement production systems used higher biocide application rates than the smallholder (A1 resettlement and CA) systems. In the former production systems, the growers were better-resourced and tended to afford the recommended routine preventive and curative fungicide sprays. As anticipated, significant positive yield-biocide use relationships were observed (Fig. 5). The gradients of the biocide use-yield relationship in the CA production system were the largest compared to other production systems, whilst the least gradient was observed in the biocide use-yield relationship of the LSC production system (Fig. 5). Therefore, this indicates that the highest yield response to biocide use was in the CA production system and that the least response was in the LSC production system. This implies that biocide use in the LSC system was approaching maximum levels. The highest yield response observed in the $\mathrm{CA}$ system probably suggests that biocide use is important to increase yield in this sector. Knowledge of Integrated Pest Management (IPM) was completely absent among all the growers sampled. Hence there is opportunity for potato growers in Zimbabwe to learn and apply IPM techniques and lower biocides use while maintaining or even increasing yields. According to Kromann et al. (2014), potato IPM for disease management involves integrating the use of resistant cultivars, fungicides and grower training. In order for farmers to adopt new technologies, it is important for them to understand the economic, ecological and practical benefits of the technology (Kromann et al. 2014). Farmer training in Zimbabwe is the principal role of the government extension agency, AGRITEX.

The agro-chemicals business in Zimbabwe is dominated by only two major companies. These companies have a distribution network through agro-dealers covering all the crop farming agro-ecological areas. Therefore the same biocides are available to all the potato farmers with variation being in the dosage/application rate due to management practice and/or to the degree of severity of insect pest infestation or disease being addressed. Common preventive fungicides for blights include Bravo $500 \mathrm{FW}$ (active ingredient, a.i. chlorothalonil) and Mancozeb, while curative fungicides include Ridomil Gold (a.i. mefenoxam), Milraz 76 WP (a.i. cymoxanil and propineb), and Folicur 250 EC (a.i. tebuconazole). Copper oxychloride 50 WP is the common fungicide for Bacterial wilt. Common insecticides used include Nemacur 400 EC (a.i. fenamiphos) for nematodes, Karate (a.i. lambda-cyhalothrin) for cutworms, Monocrotophos (a.i. dimethyl(E)-1-methyl-2-(methylcarbamoyl)vinyl phosphate) for potato tuber moth, Trigard 75-WP (a.i. cyromazine) for leaf miner, Dimethoate 40 EC (a.i. organophosphorus) and Marshal 25 EC (a.i. carbosulfan) for aphids and red spider mite, Pyrinex 48-EC (a.i. xylene) for wireworms and white grub.

Herbicide application rates were not significantly different $(\mathrm{p}<0.05)$ among the production systems (Table 5). Generally growers followed the manufacturer recommendations for herbicide use hence the tendency to use similar dosages. The most commonly used herbicides were Metolochlor and Metribuzine. Similarly, nematicide use was not significantly different ( $\mathrm{p}<0.05$ ) among the production systems (data not shown) because growers mostly applied them in accordance with manufacturer instructions. 



Fig. 5. Biocide use relationships with actual potato yield in the different potato production systems in Zimbabwe. 


\section{Seed rate}

The seed rate was significantly different $(\mathrm{p}<.001)$ among the production systems (Table 5). It ranged from an average of 990 to $2269 \mathrm{~kg} \mathrm{ha}^{-1}$ in the A1-resettlement and LSC production systems, respectively (Table 5). However, the general seeding rate reported was 2.0 to $2.5 \mathrm{t}$ $\mathrm{ha}^{-1}$ for ware potato and 2.5 to $3.3 \mathrm{t} \mathrm{ha}^{-1}$ for seed potato production (Manzira 2010). Less weight of seed was used with small to medium size tubers. In Zimbabwe, small size seed is in the 25 to $37.5 \mathrm{~mm}$ diameter range, whereas medium size seed falls in the 37.5 to $50 \mathrm{~mm}$ range. Growers preferred the small to medium size seed to reduce seed costs.

\section{Potato production systems in Zimbabwe: cultivars grown}

Tables 6 and 7 show the potato cultivar grown among growers in the Eastern Highlands and Highveld areas of Zimbabwe, respectively. Growers were asked on the cultivars they used and it was possible for one grower to mention more than one cultivar. Use of cultivar depended on many factors such as availability, cost, suitability to the grower's agroecological conditions and targeted market. Amethyst, a locally bred cultivar, was the most grown and it occupied the largest area followed by BP1, originally from South Africa. Both cultivars are very old and were grown since the early 1980s (Joyce, 1988). The use of the two cultivars was attributable to good yield and tolerance to late blight (Phytophthora infestans). Amethyst is a late maturing cultivar (17-19 weeks after planting) and has a high level of tolerance to late blight. BP1 is the earliest commercial variety on the market, maturing in 1415 weeks after planting and is moderately tolerant to late blight. These attributes have probably led to its continued use. Under good management, the two cultivars have been reported to yield in excess of $30 \mathrm{t} \mathrm{ha}^{-1}$ (Manzira 2010). Other cultivars being grown include Montclare, Jasper and KY20, all locally bred. Mondial, recently registered in 2012, is a Dutch cultivar that was introduced from South Africa and is also steadily gaining popularity, especially in the Eastern Highlands. The local potato breeding programme stopped since the turn of the millennium, mainly due to financial constraints and a high breeder staff turnover in government service. Cultivar trials are still being conducted, although with imported generation zero material of some cultivars. The country is not self-sufficient in terms of seed supply. More than $30 \%$ of the seed requirement is imported annually from neighbouring South Africa in order to meet the steadily increasing grower needs (Manzira C, personal communication, 2013).

Availability of certified seed is limited. Only one company is in the seed potato business. Besides, the company operates one outlet located in the capital city Harare making the access to seed difficult to many growers. Growers tend to use farm retained seed twice before they get certified seed.

Table 6. Irish potato cultivar use in the four production systems in the Eastern Nyanga Highlands farming area of Zimbabwe, obtained from grower surveys conducted in the period $2011-2014$.

\begin{tabular}{|c|c|c|c|c|}
\hline & $\begin{array}{l}\text { Large Scale } \\
\text { Commercial }\end{array}$ & $\begin{array}{c}\text { A2- } \\
\text { Resettlement }\end{array}$ & $\begin{array}{c}\text { A1- } \\
\text { Resettlement }\end{array}$ & $\begin{array}{c}\text { Communal } \\
\text { Area }\end{array}$ \\
\hline \multicolumn{5}{|c|}{ Cultivar grown [\% of growers sampled] } \\
\hline BP1 & 100 & 90 & 60 & 60 \\
\hline Amethyst & 100 & 75 & 60 & 60 \\
\hline Montclare & 20 & 20 & 50 & 50 \\
\hline Jasper & 20 & 20 & 50 & 50 \\
\hline Mondial & 20 & 10 & 20 & 20 \\
\hline KY20 & 10 & 10 & 10 & 10 \\
\hline
\end{tabular}

Note: Some growers grew more than one cultivar 
Table 7. Irish potato cultivar use in the production systems in the different Highveld potato farming areas of Zimbabwe, obtained from grower surveys conducted in the period $2011-2014$

\begin{tabular}{|c|c|c|c|c|c|c|c|c|c|c|c|c|}
\hline & \multicolumn{2}{|c|}{ Harare } & \multicolumn{2}{|c|}{ Bindura } & \multicolumn{2}{|c|}{ Chegutu } & \multicolumn{2}{|c|}{ Chinhoyi } & \multicolumn{2}{|c|}{ Karoi } & \multicolumn{2}{|c|}{ Nyanga Quarantine } \\
\hline & LSC & $\mathbf{A 2}$ & LSC & A2 & LSC & $\mathbf{A 2}$ & LSC & $\mathbf{A 2}$ & LSC & $\mathbf{A 2}$ & LSC & $\mathbf{A 2}$ \\
\hline \multicolumn{13}{|c|}{ Cultivar grown [\% of growers sampled] } \\
\hline BP1 & 20 & 100 & 100 & 100 & 100 & 100 & 50 & 50 & 100 & 67 & 33 & 50 \\
\hline Amethyst & 20 & 0 & 100 & 100 & 100 & 100 & 100 & 100 & 100 & 67 & 33 & 100 \\
\hline Mnandi & 40 & 0 & 0 & 0 & 0 & 0 & 50 & 50 & 0 & 0 & 0 & 0 \\
\hline Mondial & 20 & 0 & 0 & 0 & 0 & 0 & 0 & 0 & 0 & 0 & 0 & 0 \\
\hline Jasper & 0 & 0 & 0 & 0 & 0 & 0 & 0 & 0 & 0 & 33 & 0 & 25 \\
\hline Montclare & 0 & 0 & 0 & 0 & 0 & 0 & 0 & 0 & 0 & 0 & 33 & 50 \\
\hline KY20 & 0 & 0 & 0 & 0 & 0 & 0 & 0 & 0 & 0 & 0 & 33 & 25 \\
\hline
\end{tabular}

Key: LSC = Large Scale Commercial, A2 = A2 Resettlement; some growers grew more than one cultivar. 


\section{Conclusions and recommendations}

The case of the Irish potato production system in Zimbabwe showed a steady increasing trajectory of area, yield and total production of the crop in an era of uncertainties following the landmark agrarian reforms initiated in 2000. Several inferences can be made from this study. These include seed shortages and the very depressed seed breeding activities needed to answer grower problems such as low yield, low pest and diseases tolerance that is reflected in the rather high biocide application rates. High synthetic fertiliser use rates were observed in the large-scale and A2-resettlement systems. It is important therefore to move the fertiliseryield relationship to a more efficient level through appropriate interventions to shift yield upwards and improve nutrient-use efficiency. Such management interventions include better nutrient management, high-yielding cultivars, water management, pest and disease management. Smallholder potato growers (A1 and CA production systems) are limited to the Eastern Nyanga Highlands and there is a need to create appropriate awareness among smallholder growers in the Highveld agro-ecological zone to grow the crop under rain-fed conditions. A positive development is that the A2 resettlement production system is slowly merging into the large-scale commercial system in terms of input application rates, level of mechanisation and irrigation infrastructure and potato yield.

This case study of the Irish potato production system in Zimbabwe can be adopted as a model to study and analyse potato production systems in the region and in other countries. It can also be readily adopted to study and analyse other crop production systems besides Irish potato in the country and beyond.

\section{Compliance with Ethical Standards}

This research was conducted under the Wageningen University and Research Centre Sandwich $\mathrm{PhD}$ programme of the Netherlands (Grant number: 318330), with additional funding from the Chinhoyi University of Technology, Zimbabwe (Grant number: RB2240) for field data collection in Zimbabwe. The authors gratefully acknowledge the financial support from these two institutions. We express special thanks too to stakeholders in the potato industry in Zimbabwe and the farmers that provided the data analysed in this manuscript.

This manuscript has not been submitted to any other journal for simultaneous consideration, and neither has it been published previously in part nor in full.

Conflict of Interest: The authors declare that they have no conflict of interest.

\section{References}

Anonymous (1904) Economic Entomology. The Rhodesian Agricultural Journal, pp 90-93

Bell AB (1927) Statistics of Summer Crops grown by Europeans in Southern Rhodesia for the season 1925 - 1926. The Rhodesia Agricultural Journal 24:135-154

CSO (Central Statistics Office) (1993) Crop Production on Large Scale Commercial Farms, CSO, Harare, Zimbabwe, July 1993

CSO (Central Statistics Office) (1996) Crop Production on Large Scale Commercial Farms, CSO, Harare, Zimbabwe, August 1996

CSO (Central Statistics Office) (1999) Crop Production on Large Scale Commercial Farms, CSO, Harare, Zimbabwe, August 2000

CSO (Central Statistics Office) (2001) Crop Production on Large Scale Commercial Farms, CSO, Harare, Zimbabwe, July 2001

CSO (Central Statistics Office) (2002) Crop Production on Large Scale Commercial Farms, CSO, Harare, Zimbabwe, June 2005 
Chimoio M (2013) Potato smuggling still rife. The Zimbabwean. http://www.thezimbabwean.co/business/economy/63547/potato-smuggling-stillrife.html. Accessed 10 February 2013

Chuan L, He P, Pampolino MF, Johnston AM, Jin J, Xu X, Zhao S, Qiu S and Zhou W (2013) Establishing a scientific basis for fertilizer recommendations for wheat in China: Yield response and agronomic efficiency. Field Crops Research 140:1-8

Conant RT, Aaron BB and Peter RG (2013) Patterns and trends in nitrogen use and nitrogen recovery efficiency in world agriculture. Glob. Biogeochemical Cycles 27:558-566

Dube M (2013) Farmers cry foul over GMO potatoes. The Standard. http://www.thestandard.co.zw/2013/07/28/farmers-cry-foul-over-gmo-potatoes/.

Accessed 15 August 2013

Food and Agriculture Organization of the United Nations (FAO) (2006) Fertilizer use by crop in Zimbabwe. Land and Plant Nutrition Management Service, Land and Water Development Division, Rome, http://www.fao.org/docrep/009/a0395e/a0395e00.HTM Accessed 21 November 2014

Food and Agriculture Organization of the United Nations (FAO) (2005) Fertilizer use by crop in South Africa. Land and Plant Nutrition Management Service, Land and Water Development Division, Rome, ftp://ftp.fao.org/agl/agll/docs/fertusesouthafrica.pdf. Accessed 28 October 2014

Food and Agriculture Organization Statistics (FAOSTAT) (2013). http://faostat3.fao.org Accessed 7 October 2014

Haile W and Mamo T (2013) The effect of Potassium on the Yields of Potato and Wheat grown on the Acidic Soils of Chencha and Hagere Selam in Southern Ethiopia. International Potash Institute Research Findings 3-8

Haverkort AJ, Sandana P and J Kalazich (2014) Yield Gaps and Ecological Footprints of Potato Production Systems in Chile. Potato Res 57:13-31

Jack RW (1909) Regulations Affecting the Importation of Potatoes. The Rhodesia Agricultural Journal. 96-100

Joyce MJ (1982a) Potato Production in Zimbabwe. In: Nganga S (Ed) Potato Development and Transfer of Technology in Tropical Africa. International Potato Center, Addis Ababa, Ethiopia

Joyce MJ (1982b) Some Aspects of Seed Potato Production in Zimbabwe, International Potato Course: Production, Storage, and Seed Technology, Report of Participants, International Agricultural Centre, Wageningen, The Netherlands.

Joyce MJ (1988) Potato Varietal Development Programme in Zimbabwe. Paper presented at the Regional Seed Potato Workshop, Harare, Zimbabwe, 22-27 February 1988.

Kagoungo WP, Gildemacher P, Demo P, Wagoire W, Kinyae P, Andrade J, Forbes G, Fuglie $\mathrm{K}$ and G Thiele (2008) Farmer practices and adoption of improved potato varieties in Kenya and Uganda. CIP, Lima, Peru 5:42

Kromann P, Miethbauer T, Ortiz O and Forbes GA (2014) Review of potato biotic constraints and experiences with Integrated Pest Management interventions. In: Pimentel D and Peshin R (eds) Integrated Pest Management. DOI 10.1007/978-94-007-7796-5_10, 246-264

Lassaletta L, Billen G, Grizzetti B, Anglade J and Garnier J (2014) 50 year trends in nitrogen use efficiency of world cropping systems: the relationship between yield and nitrogen input to Cropland. Environ Res Lett 9:105011

Manzira C (2010) Potato production handbook. Potato seed Association, Harare, Zimbabwe Ministry of Lands and Rural Resettlement (MLRR) (2009) Memorandum to Cabinet by the 
Minister of Lands and Rural Resettlement Hon. Murerwa HM (MP) On the update on Land Reform and Resettlement Programme. Ministry of Lands and Rural Resettlement, August 2009.

Moyo S (2011) Three decades of agrarian reform in Zimbabwe. The Journal of Peasant Studies. 389(3):493-531. DOI: 10.1080/03066150.2011.583642

Penning de Vries FWT and Rabbinge R (1995) Models in research and education, planning and practice. In: Haverkort AJ and MacKerron DKL (eds) Potato Ecology and Modelling of Crops Under Conditions Limiting Growth. Kluwer Academic Publishers, Dordrecht, pp 1-18

Rukuni M and CK Eicher (1994) Zimbabwe's Agricultural Revolution. University of Zimbabwe Publications, Harare.

Sutton MA, Bleeker A, Howard CM, Bekunda M, Grizzetti B, de Vries W, van Grinsven HJM, Abrol YP, Adhya TK, Billen G, Davidson EA, Datta A, Diaz R, Erisman JW, Liu XJ, Oenema O, Palm C, Raghuram N, Reis S, Scholz RW, Sims T, Westhoek H, Zhang FS, Ayyappan S, Bouwman AF, Bustamante M, Fowler D, Galloway JN, Gavito ME, Garnier J, Greenwood S, Hellums DT, Holland M, Hoysall C, Jaramillo VJ, Klimont Z, Ometto JP, Pathak H, Plocq-Fichelet V, Powlson D, Ramakrishna K, Roy A, Sanders K, Sharma C, Singh B, Singh U, Yan XY and Zhang Y (2013) Our Nutrient World: The challenge to produce more food and energy with less pollution. Global Overview of Nutrient Management Centre for Ecology and Hydrology, Edinburgh on behalf of the Global Partnership on Nutrient Management (GPNM)and the International Nitrogen Initiative(INI), 128pp, http://www.igbp.net/publications. Accessed 7 October 2014

The Herald (2011) Zimbabwe: High Costs of Production Frustrate Seed Potato Farmers. The Herald $21^{\text {st }}$ October 2011

The Herald (2012) Potato declared strategic security food crop. The Herald, $18^{\text {th }}$ May, 2012.

Timson SD (1946) The Potato (Solanum tuberosum): methods of cultivation in southern Rhodesia. The Rhodesia Agricultural Journal. 43:146-167

USAID (United States Agency for International Development) (2013) Zimbabwean farmers advised to take up potato production. USAID's Smallholder Technology and Access to Markets Programme in Zimbabwe.

VSN International (2011) GenStat for Windows $16^{\text {th }}$ Edition. VSN International, Hemel Hempstead, United Kingdom, http://www.vsni.co.uk/webstore/software/genstat/. Accessed 7 October 2014

Vincent V and Thomas RG (1960) An agricultural survey of Southern Rhodesia: Part I: agroecological survey. Government Printers, Salisbury.

Vincent V and Thomas, RG (1961) An agro-ecological survey of Southern Rhodesia: Part I agro-ecological survey. Government Printers, Salisbury.

World Bank (2014) Trading Economics. http://www.tradingeconomics.com. Accessed 7 October 2014 
Supplementary material. Soil characterisation of the major Irish potato growing environments in Zimbabwe.

Table S1. Average soil characteristics of Irish potato growers in the two production systems in the major potato farming areas of Zimbabwe, interviewed in the period $2011-2014$.

\begin{tabular}{|c|c|c|c|c|c|c|c|c|c|c|c|c|}
\hline & \multicolumn{2}{|c|}{ Harare } & \multicolumn{2}{|c|}{ Bindura } & \multicolumn{2}{|c|}{ Chegutu } & \multicolumn{2}{|c|}{ Chinhoyi } & \multicolumn{2}{|c|}{ Karoi } & \multicolumn{2}{|c|}{ Nyanga Quarantine } \\
\hline & LSC & A2 & LSC & $\mathbf{A 2}$ & LSC & A2 & LSC & A2 & LSC & A2 & LSC & A2 \\
\hline Fine sand $(0.25-0.02 \mathrm{~mm})[\%]$ & 31 & 33 & 31 & 33 & 27.5 & 29.8 & 43.0 & 27.3 & 39.5 & 41.3 & 39.7 & 31.5 \\
\hline Medium sand $(0.25-0.5 \mathrm{~mm})[\%]$ & 9 & 7 & 13 & 7 & 16.0 & 14.8 & 9.0 & 12.3 & 20.8 & 23.0 & 18.3 & 20.5 \\
\hline Coarse sand $(0.5-2.0 \mathrm{~mm})[\%]$ & 4 & 3 & 5 & 3 & 10.0 & 8.0 & 2.0 & 4.3 & 21.3 & 5.7 & 12.7 & 16.9 \\
\hline Silt $(0.02-0.002 \mathrm{~mm})[\%]$ & 26 & 22 & 21 & 22 & 17.5 & 19.0 & 17.0 & 24.0 & 9.5 & 17.7 & 15.0 & 15.0 \\
\hline Clay $(<0.002 \mathrm{~mm})[\%]$ & 30 & 36 & 31 & 36 & 29.0 & 28.4 & 29.0 & 32.0 & 9.0 & 12.3 & 14.7 & 16.2 \\
\hline Organic matter content $[\%]$ & 2.9 & 0.8 & 0.9 & 0.7 & 0.4 & 1.3 & 1.3 & 2.4 & 1.1 & 0.8 & 6.5 & 5.0 \\
\hline $\mathrm{pH}\left(\right.$ in $\left.0.01 \mathrm{M} \mathrm{CaCl}_{2}\right)$ & 5.4 & 4.9 & 4.9 & 6.0 & 6.1 & 5.72 & 5.6 & 5.9 & 5.5 & 6.1 & 4.5 & 4.5 \\
\hline Mineral N (initial) [ppm] & 32.5 & 6.5 & 12.5 & 16.6 & 25.5 & 16.2 & 10.0 & 21.3 & 15.3 & 19.3 & 9.0 & 27.7 \\
\hline Mineral N (after incubation) [ppm] & 49.0 & 33.5 & 32.5 & 30.8 & 45.5 & 35.8 & 21.0 & 51.7 & 34.8 & 29.0 & 47.5 & 53.0 \\
\hline Available $\mathrm{P}$ (resin extract) $\left[\mathrm{ppm} \mathrm{P}_{2} \mathrm{O}_{5}\right]$ & 138.5 & 14.5 & 53.0 & 44.8 & 56.5 & 35.8 & 13.0 & 20.3 & 43.8 & 19.0 & 31.5 & 5.5 \\
\hline Exchangeable K (mg equivalents per $100 \mathrm{~g}$ soil) & 1.0 & 0.3 & 0.3 & 0.5 & 7.9 & 4.1 & 0.1 & 1.0 & 1.2 & 3.0 & 0.10 & 0.16 \\
\hline Exchangeable $\mathrm{Ca}$ (mg equivalents per $100 \mathrm{~g}$ soil) & 5.8 & 4.8 & 9.6 & 8.2 & 6.4 & 10.2 & 1.7 & 2.5 & 1.6 & 2.2 & 1.3 & 1.7 \\
\hline Exchangeable $\mathrm{Mg}$ (mg equivalents per $100 \mathrm{~g}$ soil) & 1.7 & 1.7 & 5.5 & 4.3 & 2.1 & 2.9 & 1.2 & 1.9 & 1.1 & 1.5 & 0.6 & 0.7 \\
\hline
\end{tabular}

Key: LSC = Large Scale Commercial, A2 = A2 Resettlement 
Table S2. Soil characteristics of Irish potato growers in different production systems in the Nyanga (excluding the Nyanga Quarantine Area) farming area interviewed in the period 2011-2014, Zimbabwe.

\begin{tabular}{|c|c|c|c|c|c|c|c|c|}
\hline \multirow[t]{2}{*}{ Characteristic } & \multicolumn{2}{|c|}{ Large Scale Commercial } & \multicolumn{2}{|c|}{ A2-Resettlement } & \multicolumn{2}{|c|}{ A1-Resettlement } & \multicolumn{2}{|c|}{ Communal Area } \\
\hline & average & range & average & range & average & range & average & range \\
\hline Fine sand $(0.25-0.02 \mathrm{~mm})[\%]$ & 43.0 & $29.1-47.8$ & 27.8 & $19.0-33.0$ & 25.4 & $21.0-32.0$ & 34.2 & $12.0-63.0$ \\
\hline Medium sand $(0.25-0.5 \mathrm{~mm})[\%]$ & 23.2 & $26.6-34.5$ & 31.3 & $27.0-39.0$ & 28.2 & $11.0-38.0$ & 10.7 & $2.0-32.0$ \\
\hline Coarse sand $(0.5-2.0 \mathrm{~mm})[\%]$ & 9.1 & $6.5-18.7$ & 14.5 & $8.0-19.0$ & 25.0 & $16.0-38.0$ & 9.2 & $1.0-22.0$ \\
\hline Silt $(0.02-0.002 \mathrm{~mm})[\%]$ & 4.0 & $3.0-12.4$ & 10.0 & $6.0-16.0$ & 6.9 & $3.0-14.0$ & 17.5 & $3.0-39.0$ \\
\hline Clay $(<0.002 \mathrm{~mm})[\%]$ & 20.0 & $18.2-23.4$ & 18.5 & $14.0-21.0$ & 14.3 & $8.0-38.0$ & 28.4 & $6.0-52.0$ \\
\hline Organic matter content [\%] & 2.43 & $2.01-3.90$ & 1.6 & $1.2-2.2$ & 1.2 & $0.5-4.2$ & 3.1 & $0.3-7.8$ \\
\hline $\mathrm{pH}$ (in $0.01 \mathrm{M} \mathrm{CaCl}_{2}$ ) & 5.2 & $4.8-5.5$ & 4.5 & $4.4-4.8$ & 4.8 & $4.1-5.8$ & 4.3 & $4.1-5.0$ \\
\hline Mineral N (initial) [ppm] & 10.0 & $2.4-36.5$ & 9.5 & $3.0-23.0$ & 12.9 & $5.0-33.0$ & 20.6 & $3.0-69.0$ \\
\hline Mineral N (after incubation) [ppm] & 33.0 & $17.6-87.2$ & 34.0 & $19.0-52.0$ & 34.6 & $22.0-62.0$ & 53.0 & $17.0-111.0$ \\
\hline Available $\mathrm{P}$ (resin extract) $\left[\mathrm{ppm} \mathrm{P}_{2} \mathrm{O}_{5}\right]$ & 14.0 & $3.3-71.8$ & 9.0 & $3.0-19.0$ & 15.7 & $2.0-61.0$ & 11.5 & $1.0-47.0$ \\
\hline Exchangeable K (mg equivalents per $100 \mathrm{~g}$ soil) & 0.64 & $0.40-2.11$ & 0.13 & $0.08-0.19$ & 0.3 & $0.1-1.5$ & 0.3 & $0.1-1.9$ \\
\hline Exchangeable $\mathrm{Ca}$ (mg equivalents per $100 \mathrm{~g}$ soil) & 2.03 & $0.83-2.61$ & 1.6 & $1.1-2.3$ & 1.3 & $0.4-2.1$ & 1.5 & $0.4-4.8$ \\
\hline Exchangeable $\mathrm{Mg}$ (mg equivalents per $100 \mathrm{~g}$ soil) & 1.12 & $0.55-1.88$ & 0.6 & $0.4-0.9$ & 0.7 & $0.3-1.2$ & 0.7 & $0.3-2.5$ \\
\hline
\end{tabular}


Table S3. Climatic characteristics in the Nyanga Irish potato farming area of Zimbabwe, average over 1985 - 2010.

\begin{tabular}{|c|c|c|c|c|c|}
\hline Month & $\begin{array}{l}\text { Mean monthly } \\
\text { precipitation } \\
{\left[\mathrm{mm} \mathrm{month}^{-1}\right]}\end{array}$ & $\begin{array}{c}\text { Mean monthly } \\
\text { maximum temperature } \\
{\left[{ }^{\circ} \mathrm{C}\right]}\end{array}$ & $\begin{array}{c}\text { Mean monthly } \\
\text { minimum temperature } \\
{\left[{ }^{\circ} \mathrm{C}\right]}\end{array}$ & $\begin{array}{l}\text { Mean monthly } \\
\text { radiation } \\
{\left[\mathrm{MJ} \mathrm{m}^{-2} \mathrm{~d}^{-1}\right]}\end{array}$ & $\begin{array}{c}\text { Mean monthly } \\
\text { evaporation } \\
{\left[\mathrm{mm} \mathrm{d}^{-1}\right]}\end{array}$ \\
\hline January & 339.9 & 22.4 & 13.1 & 20.2 & 3.8 \\
\hline March & 162.3 & 22.1 & 12.4 & 19.7 & 3.7 \\
\hline April & 70.9 & 21.0 & 10.3 & 18.2 & 3.5 \\
\hline May & 23.9 & 19.7 & 7.6 & 16.3 & 3.2 \\
\hline August & 14.8 & 19.6 & 6.3 & 18.5 & 4.0 \\
\hline September & 21.1 & 22.4 & 8.9 & 21.6 & 5.5 \\
\hline October & 66.9 & 22.9 & 10.8 & 22.8 & 5.7 \\
\hline November & 125.7 & 23.2 & 12.1 & 22.8 & 4.9 \\
\hline December & 250.0 & 22.4 & 12.6 & 20.2 & 3.8 \\
\hline
\end{tabular}

Source: Meteorological Services Department, MSD, Zimbabwe, Nyanga Experiment Station weather station, $18^{\circ} 13^{\prime} \mathrm{S}, 32^{\circ} 44^{\prime} \mathrm{N}$ 
Table S4. Climatic characteristics in the Chinhoyi Irish potato farming area of Zimbabwe, average over 1985 - 2010.

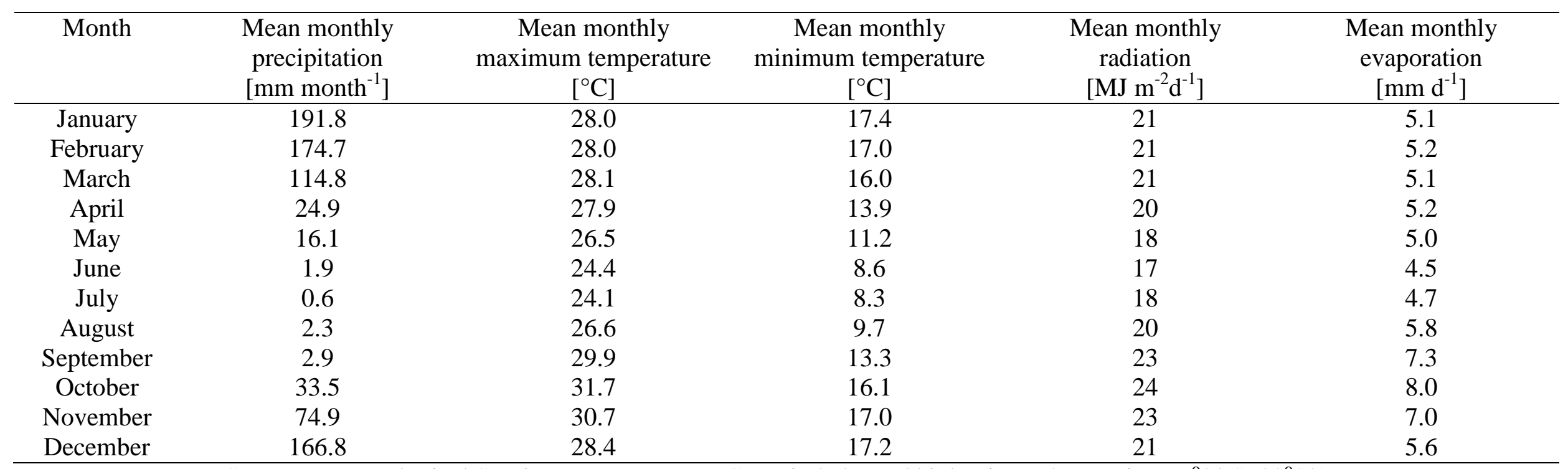

Source: Meteorological Services Department, MSD, Zimbabwe, Chinhoyi weather station $17^{\circ} 23^{\prime} \mathrm{S}, 30^{\circ} 23^{\prime} \mathrm{N}$ 
Table S5. Climatic characteristics in the Karoi Irish potato farming area of Zimbabwe, average over 1985 - 2010.

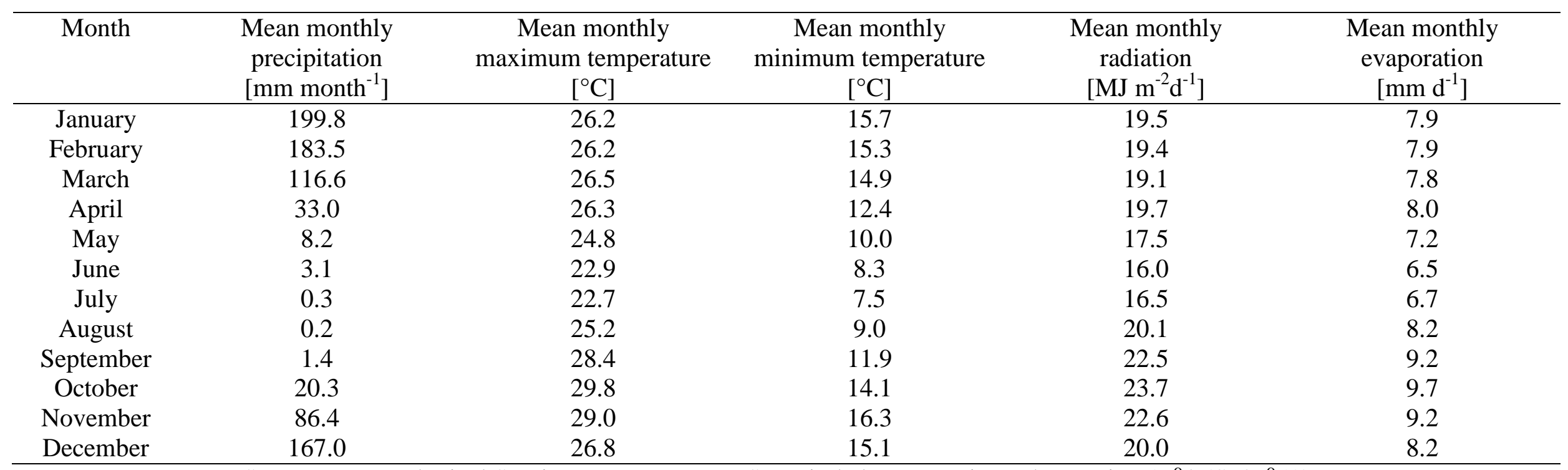

Source: Meteorological Services Department, MSD, Zimbabwe, Karoi weather station $16^{\circ} 49^{\prime} \mathrm{S}, 29^{\circ} 51^{\prime} \mathrm{N}$ 
Table S6. Climatic characteristics in the Harare (including Bindura and Chegutu) Irish potato farming area of Zimbabwe, average over $1985-2010$.

\begin{tabular}{|c|c|c|c|c|c|}
\hline Month & $\begin{array}{l}\text { Mean monthly } \\
\text { precipitation } \\
{\left[\mathrm{mm} \mathrm{month}^{-1}\right]}\end{array}$ & $\begin{array}{c}\text { Mean monthly } \\
\text { maximum temperature } \\
{\left[{ }^{\circ} \mathrm{C}\right]}\end{array}$ & $\begin{array}{c}\text { Mean monthly } \\
\text { minimum temperature } \\
{\left[{ }^{\circ} \mathrm{C}\right]}\end{array}$ & $\begin{array}{l}\text { Mean monthly } \\
\text { radiation } \\
{\left[\mathrm{MJ} \mathrm{m}^{-2} \mathrm{~d}^{-1}\right]} \\
\end{array}$ & $\begin{array}{l}\text { Mean monthly } \\
\text { evaporation } \\
{\left[\mathrm{mm} \mathrm{d}^{-1}\right]} \\
\end{array}$ \\
\hline January & 218.4 & 27.0 & 16.4 & 20 & 5.0 \\
\hline March & 120.4 & 26.9 & 15.2 & 20 & 4.9 \\
\hline April & 32.2 & 26.1 & 12.6 & 20 & 4.7 \\
\hline May & 14.7 & 24.6 & 9.7 & 18 & 4.2 \\
\hline June & 3.2 & 22.4 & 7.4 & 17 & 3.8 \\
\hline September & 2.7 & 27.9 & 12.5 & 23 & 7.1 \\
\hline October & 30.0 & 29.4 & 15.0 & 24 & 7.7 \\
\hline November & 85.8 & 28.9 & 16.1 & 22 & 6.9 \\
\hline December & 189.0 & 27.4 & 16.3 & 20 & 5.3 \\
\hline
\end{tabular}

Source: Meteorological Services Department, MSD, Zimbabwe, Belvedere weather station $17^{\circ} 49^{\prime} \mathrm{S}, 31^{\circ} 02^{\prime} \mathrm{N}$. 